\title{
Correspondence
}

\section{The joys of research in retirement}

After retiring some ten years ago at the age of 65 , I still wanted to do some worthwhile research (Nature 521, 20-23; 2015).

I had only a chair and a table for support. These props came courtesy of my former employer, along with online access to the scientific literature. I was originally a researcher in two very different fields - surface science and nanoparticle-related health effects - so I set about re-evaluating publications in both areas. New ideas emerged, sparking successful collaborations with former colleagues who had the necessary equipment to investigate them.

I have written and published 30 mostly single-author papers since retirement. Most notable is a 123-page review that took me almost 2 years to prepare, allowing me to invalidate a theory that was more than 30 years old (K. Wittmaack Surf. Sci. Rep. 68, 108-230; 2013). I reckon that I have learned more per unit time during this phase than I did during my 'active' career. And still I keep going.

Colleagues with retirement in sight should give up the idea that science can only be advanced with a sizeable research team. Sit down and take the literature to pieces, then put the puzzle together again in light of your newly gained insight. Gratifying work awaits. Klaus Wittmaack HelmholtzZentrum München, Institute of Radiation Protection, Germany. wittmaack@helmholtz-muenchen.de

\section{Phosphate mining risks atoll culture}

Mataiva atoll in the Pacific Ocean has an unusual morphology: its central lagoon is divided into numerous shallow basins by a network of slightly submerged coral shoals. This extremely rare geological feature, known as a reticulated lagoon, is now under threat from the global demand for

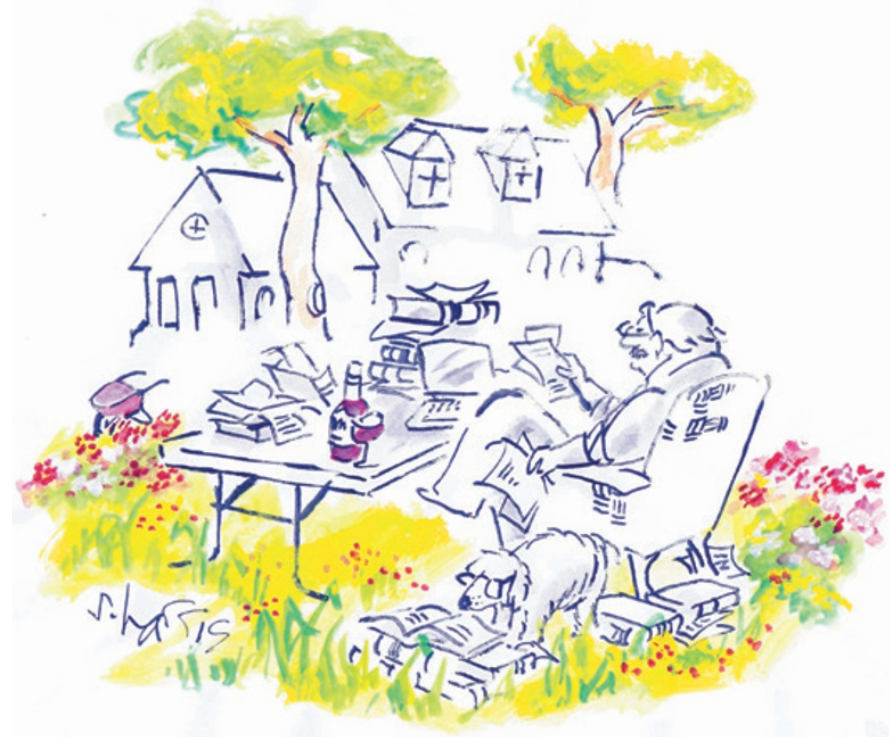

phosphate, used in agriculture.

International companies and the government of French Polynesia have attempted to mine Mataiva's rich phosphate resources since the 1980 s, but have so far been thwarted by its inhabitants.

Opposition was on the basis of the potentially disruptive effects of mining on the population's identity and on its culture of coconut farming and fishing. An 18-month test of the extraction process in 1986 destroyed and polluted fish habitats to the extent that people reportedly could not eat lagoon fish for 10 years. Island people also feared the loss of land rights, because their livelihoods depend on farming and drying coconut flesh (copra).

The government this year announced its decision to resume phosphate extraction. Resistance is now dangerously weakened as the atoll's elders dwindle and the younger generation moves away, severing the cultural attachment to the atoll's traditional way of life. The world's geological patrimony is again at stake. Alexandre Magnan Institute for Sustainable Development and International Relations (IDDRI), Sciences Po, Paris, France. Virginie Duvat Littoral, Environment and Societies Research Unit (LIENSs, UMR 7266), University of La Rochelle and
CNRS, La Rochelle, France. alexandre.magnan@iddri.org

\section{Share surplus animal tissue}

Strict regulations govern the use of laboratory animals in research (see, for example, K. Davies Nature 521, 7; 2015), but scientists are under increasing pressure to justify their experiments and address public concerns (Nature 520, 271-272; 2015). Initiatives such as SEARCHBreast avoid the need to set up further in vivo models by using surplus archival tissue from previous animal studies.

SEARCHBreast (for 'Sharing Experimental Animal Resources: Coordinating Holdings in Breast Cancer') is a searchable platform of tissues, resources and information derived from animal models of breast cancer (www.searchbreast.org). These materials can be deployed for characterizing tumour biomarkers and genetically engineered animal models, for example, or for investigating treatment effects on archived human-to-mouse xenografts.

The 'SEARCH' blueprint translates to other diseases: for example, ShARM (Shared Ageing Research Models; www.sharmuk.org) aims to accelerate research on ageing. Such resources support official 'replacement, refinement and reduction' policies (see www.nc3rs.org.uk/the-3rs) and save time and money.

Valerie Speirs ${ }^{\star}$ Leeds Institute of Cancer and Pathology, University of Leeds, UK.

v.speirs@leeds.ac.uk ${ }^{*}$ On behalf of 7 correspondents (see go.nature.com/gthlzc for full list).

\section{Climate advisers must be astute}

Oliver Geden suggests that scientific advisers on climate should resist becoming "political entrepreneurs" by making their advice more palatable (Nature 521, 27-28; 2015). In fact, climate advisers need to be astute political entrepreneurs if they are to present the benefits of a policy change without exaggerating claims.

Political pragmatism is not for helping policy-makers to justify the status quo, but rather for presenting persuasive scientific evidence alongside other issues (D. C. Rose Nature Clim. Change 4, 1038; 2014). Entrepreneurial climate scientists can offer fresh solutions to policy-makers, point out the improvements their ideas would provide and explain how they would work in practice. These entrepreneurs take the concerns of other scientists and policy-makers into account, build professional networks, and use every opportunity to maximize political influence (M. Mintrom and P. Norman Policy Stud. J. 37, 649-667; 2009).

Optimizing science presentation does not mean compromising on technical rigour or integrity. Climate scientists can increase their understanding of how policymakers use the evidence they provide, as Geden recommends, and so deploy it more effectively to argue for policy change.

David C. Rose University of Cambridge, UK.

dcr31@hermes.cam.ac.uk 